\title{
Original Documents Relative To Canons Ashby, Northamptonshire
}

\author{
Joseph Bain F.S.A. Scot.
}

To cite this article: Joseph Bain F.S.A. Scot. (1879) Original Documents Relative To Canons Ashby, Northamptonshire, Archaeological Journal, 36:1, 95-98, DOI: 10.1080/00665983.1879.10851893

To link to this article: http://dx.doi.org/10.1080/00665983.1879.10851893

$$
\text { 册Published online: } 14 \text { Jul } 2014 .
$$

Submit your article to this journal $[\pi$

Q View related articles $₫$ 


\title{
Drtgual Documents
}

\author{
RELATINE TO CANONS ASHBY, NORTHAMPTONSHIRE. \\ Communicated by JOSEPF BAIN, F.S.A. Scot.
}

The following original charters may interest Northamptonshire antiquaries, as they relate to the Church of the "Blessed Mary of Ashby," the well known Priory of Black Canons the Augustinian Order, founded in the reign of Henry II, probably by Stephen de Leya, then lord of the manor. He was at all events its earliest benefactor, as his very interesting charter testifies, of which, with its details, an abstract is given by the laborious Baker (Hist. of Northamptonshire, vol. ii, p. 18). It occurs on the first folio of the MS. cartulary of the Priory, a clocument often referred to by Baker, and his predecessor Bridges, as being in the possession of the family of Orlebar of Hinwick, Co. Bedforl. Baker has also given an abstract (loc. at.) of the third and most curious of the charters now printed, shewing that it is contained in the MS. cartulary, and probably so are the other two. But as the cartulary has never been printed, so far as the writer understands, the full text of these.documents may perhaps be acceptable. ${ }^{1}$ The charters are Nos. 5882-3-4 of the Additional Chrirters, British Muscum, and were purchased from a London bookseller in May 1841.

Add. Charters, (5882). I.

Sciant presentes et futuri. Quod ego Henricus miles filius Rogeri de Mortona pro salute anime mee et uxoris mee et heredum meorum et pro animabus patris et matris mee Et omnium antecessorum meorum Concessi et dedi et hac presenti carta mea confirmavi Deo et Ecclesie Sancte Marie de Essebi et canonicis ibidem Deo servientibus totum dominicum quod datum fuit in maritagium cum matre mea. Scilicet. decem seiliones super Exlet. et duas seiliones super ulteriorem Bereforlanga Et tres seiliones super alterum Bereforlanga et sex seiliones et tres foreras super Hegtrelanga et duas seiliones sujer hob'ge et totam terram in Brade quam emi de Henrico le L'ab cum prato toto quod emi de predicto Henrico. Habendum et tenendum predictis canonicis in puram et perpetuam elemosinam liberam et quietam ab omni seculari servicio Hanc elemosinam meam ego et hererles mei Warantizabimus predictis canonicis contra omnes gentes Hiis testibus. Domino Symone de Pinkeni. Johanne vicario de Mortona. Roberto de Sureia. Roberto filio Hernaldi. Toma filio Felicie. Willelmo filio Ivonis de Eidona. Hugone clerico de Culw'c. Rogero priore. Mychaele de Bukgham. Warino et multis aliis.

Size 6 in. by $2 \frac{1}{2}$ in., clearly written with contractions.

$$
\text { Endorsed_-" Carta Henr) Knycht. }
$$
de xxiij seilionibz cum iij forr et alijs."

1. It may be, that, as is often the case, the cartulary does not give the lists of the attesting witnesses, always one of the most valuable cletails in an early charter as tending to fix its date. 
[Abstrnct.]

Henry the Knight son of Roger of Morton for the safety of his own and his wife's and his heirs' souls, and those of his father and mother and of all his ancestors, gives to God and the Canons of the Church of S. Mary of Essebi all the domain which was given in marriage with his mother, viz., 10 ridges of land on Exlet; and 2 ridges upon further (or (over) Bereforlang; and 3 ridges upon the other Bereforlang; and 6 ridges and 3 furrows upon Hegtrelang; and 2 ridges unon Hob'ge; and all the land in Brade which he bought from Henry "le L'al,," with the whole meadow which he bought from sair Henry. 'To be held by the Canons in pure and perpetual alms.'

"Sir Simon de Pinkeni," one of the witnesses to this deed, was probably Sir Simon of Moreton Pinkney and Sulgrave, who Hourished at the end of John's reign and the beginning of that of Henry. He was related to the Barons of Wedon, who were Lords paramount of Moreton.

\section{Add. Charters, (5883). II.}

Sciant presentes et futuri quod ego Willelmus filius Hamonis dedi et concessi et hec mea carta confirmavi Deo et Beate Marie de Esseby et canonicis ibidem Deo servientibus pro salute anime mee et pro animabus patris mei et matris mee et omnium antecessorum et successorum meorum unam dimidiam acram terre cum pertinentiis in campis de Wappeham illam scilicet que jacet in Kinewelhnl propinquior terre Benedicti filii Bartholomei ex parte orientali. Habendam et tenendam dictis canonicis de me et de heredibus meis in liberam et puram et perpetuam elemosinam. Et eggo dictus W. et heredes mei dictam tcrram cum pertinentiis dictis canonicis contra omnes homines et feminas Warantizabimus inperpetuum Quod ut ratum sit. presens scriptum sigillo meo corroboravi. Hiis testibus Rogero de Lyuns milite. Roberto de Plunptona. Ricardo de Attenestona. Alexandro de Bosco. Thomas Anegod. W'illelmo Henfrei. Henrico Pain et multis aliis.

Size 5 by $2 \frac{1}{2}$ inches. Very clearly written, with contractions. The seal is gone, but the slit for the tag remains.

$$
\text { [Abstract.] }
$$

William, son of Hamon, gives to God and the blessed Mary of Esseby and the Canons serving God there, for the safety of his own and his father's and mother's souls, and those of his ancestors and successors, one half acre of land with the pertinents in the fields of Wappenham, that namely, which lies in Kinwelluul next to the land of Benedict the son of Bartholomew on the east part. In pure and perpetual alms, \&c. Appends his seal.

Of the witnesses, Sir Roger de Lyons and Robert de Plumpton are members of early and important County families.

\section{Add. Charters, (5584). III.}

Sciant presentes et futuri quod ego Hugo Gulafre pro salute mea et pro salute uxoris mee et heredum meorum et pro animabus patris et matris mee et omnium antecessorum meorum dedi et hac presenti carta

1 The word "seilio" occurring above, is doubtless the same as the French "sillon." It is explained by Ducange to mean a piece of land of uncertain exteut : "Forera," on the same authority, is a piece of land at right angles to the ridge, no doubt to enible a plough to be turned. "Ridge and furrow" is a well known expression in our own day. 
mea confirmavi ecclesie Sancte Marie de Essebi et canonicis ibidem Deo servientibus tres virgatas terre et dimidiam in Ettenestona cum masagiis et omnibus pertinentiis et cum hominibus qui eandem terram tenebant in vilenagio. Scilicet. Estmundus Ricardus filius Randulfi. Randulfus. frater Estmundi. Seledus. Wibertus. Orsewinus. Preterea dedi et hac eadem carta confirmavi predictis canonicis unam virgatam terre in earlem villa quam Galfridus de Northona libere tenebit de eis sibi et heredibus suis sexdecim denarios annuatim reildenclo. Preterea confirmavi predictis canonicis duas virgatas terre in eadem villa quas pater meus dedit eis cum masagio et grava. Has predictas sex virgatas terre et dinnidiam tenebunt predicti canonici libere et quiete ab ommi seculari servicio quod pertinet ad me et ad heredes meos salvo forinseco servicio quantum pertinet ad sex virgatas terre et dimidiam de feudo militis quod habet in se $\mathrm{xxxy}$. virgatas terre et dimidiam. Totam predictam terram debeo ego et heredes mei warantizare predictis canonicis contra omnes homines. Testes sunt. Walkelinus Ablos Sancti Jacobi. Ricardus presbiter. Absalon presbiter. Adam clericus. Willelmus de Pluntona. Ricardus de Leuns. Henricus de Pincheni. Robertus de Leya. Henricus filius Waloin'. Radulfus Basset. Ricardus de Fardinbestun. Gilebertus de Wandevilla. Robertus de Wanci. Willelmus de Cheindedut. Galfridus de Northona, et filii eius Galfridus et Herebertus. Rogerus de Bosco. Robertus de Ettenestona. et filii Henricus et Galfridus. Walterus Luuel. Osbernus Deunte. Walkelinus de Lindona.

Size $7 \frac{3}{4}$ by 3 inches. Very clearly written, with contractions and in fine condition. No seal or tag. Eudorsed-" De terra de attenestona.

\section{Hug. Gut. de t'ra de Attenestona de donacō" [Abstract.]}

Hugh Gulafre for his own and his wife's safety and that of his heirs, and for the souls of his father and mother and of all his ancestors gives to the Church of S. Mary of Essebi and the Canons there serving Gorl three virgates and a half of land in Ettenestona with messuages \&c. and with the men who hold the sail land in vilenage viz: Estmumd, Richard son of Randulf, Randulf brother of Estmund, Seledus, Wibertus, and Orsewinus. Also gives one virgate in said vill which Galf ridus de Northona shall hold of the Canons, he and his heirs paying them $16 d$ annually. Also he confirms 2 virgates of land in the same vill which his father gave the Canons with a messuage and a grove. The Canons to hold the said six virgates and a half free of all secular service to the granter and his heirs, except as much foreign service as pertains to 61 virgates of a knight's fee, containing in itself $35 \frac{1}{2}$ virgates.

This is a curious, and, as testified by the number and character of the witnesses, an important deed, and is pointed out as such by Mr. Baker, especially in respect of its conveyance of the six villeins, and its specifying the extent of a knight's fee.

The granter was doubtless Hugo Gulafre, Lord of the Manor of Blakesley in Norton Hundred circ. 1200. Bridges' Northamptonshire, vol. ii, pp. 227, 231-2 ; and Baker, vol. ii, p. 22 .

Walkelin, Abbot of St. James, is considered by Bridges (vol. ii, p. 497) to be the same person as. Walkelin, father of William de Duston, who in 7 th of John (1205) obtained a confirmation of the lands which his father held in Duston (Newbottle Hundred) "at the time he put on the habit 
of a religious. Walkelin was elected abbot of St. James's Monastery in 26 th Henry II, and died in the 7th year of this (John's) reign."

Henry de Pincheni is either the Baron of Wedon of that ehristian name, who dier circa 1209, ancestor of the competitor for the Scottish crown, or his relative, Henry de Pinkeni of Morton Pinkeni and Sulgrave, temp. Henry II.' Some of the other witnesses belong to well known Torthamptonshire houses. Ralph Basset could trace a high juclicial lineage. He was Irobably the second son of Richard Basset, and Mauld Ridel, heiress of ("eoffry Riclel Chief Instice of England, "an eminent and learned person," as Dugrtale calls him; while his paterual grandfather, Ralph Basset, had preceder (ieoffry Ridel in the high office of Chief Justice. And what is curions, from Mauld heing an heiress, her eldest son Geoffry took her surname and arms for his life, as Dugdale points out in his Baronage.

These observations may be permitter, although coming from a stranger' to the county. Canons Ashby, the historic seat of the Dryilens, is not less linked with the name of the great poet, than with the archæological researches of its present owner in Scotland's "Ultima Thule." A Scotsman may, therefore, be presumed to take an interest in a county which, as a member of the Honour of Huntingdon, was once closely identified with the Scottish kings and princes, as many charters yet testify.

1 It is singular that Dugdale, Bridges, and Baker were unable to trace the career of Sir Henry de Pinkeni, brother and heir of Sir Robert, the competitor for the Scottish crown, except that in 1301 he sold his barony to Edward I, and in 1302 was summoned to serve in the Scottish war. Only a few days ago the writer observed the following original entry concerning him, which seems to be unknown:-

"Pynkenye.

"Domino Henrico de Pinkenye, militi, commoranti ad vadia Regis in municione ville Berewici super Twedam, capiente per diem iis pro vadiis suis, et Mauricii de Dromsagard, scutiferi sui, capientis per diem xïd a vicesimo nono Maï anno presenti quinto, usque in septimum diem Julii anno eodem finiente, utroque computato per $x l$ dies ... ... ... vj libras. Probatum."

This was in A.D. 1312 (5th Edward II). In the Horse Roll, Sir Henry's horse, a "clear bay," is valued at 20 marks ; and that of his 'Squire, a "black," at 100 shillings.

This is taken from a Muster Roll of the Garrison of Berwick on Tweed, serving under the orders of Sir Ralph of Monthermer, Lieutenant of the King in Scotland, among the Cotton MSS. in the British Museum. Part of it was printed many years ago in the appendix to the Chronicon de Lanercost out of the Scotch Club Books, and there it has lain entombed. Sir Henry, who was now in his forty-sixth year, was thus serving as a simple Knight at $2 \mathrm{~s}$. per diem. His Esquire was evidently a Scotsman, probably a cadet of the Morays of Bothwell and Drumsargard in Clydesdale. Did the Knight fall a couple of years later at Bannockburn like many of his comrades? He was fairly mounted, but not extravagantly. Some of the English knights on the border at that time had chargers worth from $£ 30$ to $£ 50$. 